\title{
薄板集成短柱の弾塑性有限変位解析 \\ ELASTIC-PLASTIC FINITE DISPLACEMENT ANALYSIS OF PLATE-ASSEMBLED COLUMN SEGMENTS
}

\author{
宇佐美 勉* · 土屋 信 洋** · 大谷恭弘***・福 本 唀士**** \\ By Tsutomu USAMI, Nobuhiro TSUTIYA, Yasuhiro OTANI and Yuhshi FUKUMOTO
}

\begin{abstract}
A finite element method based on the modified Hellinger-Reissner's principle is applied to compute the elastic-plastic post-buckling behavior of plate-assembled steel column segments. The effects of both welding residual stresses and initial plate deflections are allowed for in the analysis. Load-shortening curves of uniaxially loaded single plates are shown to be in good agreement with Little's results which are supporsed to be the most reliable solutions. Moment-thrust-curvature $(M-P-\Phi)$ curves of locally buckled box column segments are computed and, based on the results, an interaction formula for predicting the ultimate strength of box column segments in combined compression and bending is proposed.
\end{abstract}

\section{1. 緒言}

局部座屈を考えた薄板集成鋼圧縮部材（柱，はり一柱） の荷重-変形特性を厳密に解析することは非常に難しい. このような部材の挙動は種々の初期不整, とりわけ, 構 成板要素の初期たわみ，溶接による残留応力，および部 材軸線の初期曲がりに大きく左右され ${ }^{1), 21}$ ，これらのす べてを考慮して厳密に解析することはほとんど不可能に 近く, 何らかの近似解法に頼らざるを得ない. 局部座屈 を考えない圧縮部材の解析では, 断面のモ一メント-軸 力-曲率関係 $(M-P-\Phi$ 関係) を残留応力を考慮してあ らかじめ求めておき, それらを部材軸線の初期たわみを 考慮して部材の長さ方向に積分する手法がよく用いられ $る^{3)}$. この考えは局部座屈を考えた圧縮部材の解析にも 適用できると考えられる4).ただし，局部座屈が考慮で きるように，“断面”の代わりに“短柱”を考える必要 がある．短柱の構成板要素に残留応力および初期たわみ を考えることにより, 短柱の挙動 $(M-P-\Phi$ 関係) には これらの初期不整を含ませることができ, 後は局部座屈

* 正会員 工博 名古屋大学助教授 工学部土木工学科 ( ( 464 名古屋市千種区不老町)

** 正会員 工修 清水建設土木本部 技術部

*** 学生会員 工修 Purdue 大学大学院博士課程

**** 正会員 工博 名古屋大学教授 工学部土木工学科
を考えない解析と同様な計算を行えば主要な初期不整を すべて考えた圧縮部材の挙動が近似的に求められること になる.このように短柱の挙動は部材全体の挙動を解析 をするうえに重要な役割を果たすこととなる.

本研究は局部座屈を考えた薄板集成鋼圧縮部材の挙動 に関する理論的研究の第 1 段階として, 単独板要素およ び短柱要素の局部座屈後の弾塑性有限変位挙動の理論的 解析について述べたものである. 解析手法は; 薄板の弾 塑性有限変位理論に基づく有限要素法であり, 混合法に よる定式化を行っている.

圧縮板の有限変位解析に関する論文はすでに数多く発 表されているが，ここでは，本論文と関連の深い 2,3 の論文のみを取り上げ，その他の研究は文献 5) -9）の 参考文献を参照していただくことにする. 初期たわみと 残留応力を同時に考えた圧縮板の弾塑性有限変位解析と しては，わが国では有限要素法による小松・北田 ${ }^{5), 6)}$ の先駆的研究があり，その後に同研究グループにより発 表されている圧縮補剛板に関する一連の研究とともに高 く評価されている研究である. 海外では英国において多 くの研究が発表されており, 有限要素法のほかに, Rayleigh-Ritz 法, Dynamic Relaxation 法による解法

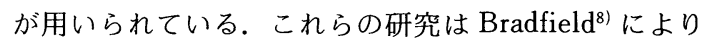
詳細にレビューされており, 各解法の概要, 特徴, さらに, 
同一の問題に対する計算結果の比較など，参考になると ころが多い。

上述のように, 有限要素法による圧縮板の弾塑性有限 変位に関する研究は数多くあるものの，ほとんどが変位 法に属する解法であり，本論文のように混合法を用いた 解法は, 弾性域での解法 ${ }^{10) \sim 12)}$ を除いて見当たらないよ うである. 本研究では三角形平板要素を用い，曲げ変形 に対しては一定応力場および線形変位場を用いる混合法 $\left(\right.$ Herrmann モデル $\left.{ }^{13)}\right)$ ，面内変形に関しては定ひずみモ デルによる変位法を混用し，移動座標法による定式化を 行っている.

\section{2. 解析方法}

\section{（1）基本仮定}

以下に示す基本仮定のもとで基礎方程式を誘導する：

(a) 薄板理論に対する Kirchhoff ${ }^{14)}$ の仮定が成り立 つ.

(b) Von Karmanのひずみ-変位関係 ${ }^{14)}$ が成り立つ.

(C) 材料は等方性の完全弾塑性体とし, Von Mises の降伏条件, Prandtl-Reuss の塑性流れ理論に従 $j^{15)}$.

(d) 変形前, 後の部材は常にたわみのない三角形平板 要素の集合として扱えるものとする.

\section{（2）接線剛性方程式の誘導}

Fig. 1 に示すように, 三角形平板要素 $($ 板厚 $=t$ ) の 中央面に $(x, y)$ 座標, それと直角方向に右手系をなす ように $z$ 軸を定める. また, 要素各辺には $(n, s)$ 座 標を $n$ 軸を辺の外向き法線方向， $s$ 軸を辺に沿って設 ける. 板の中央面の任意点の $x, y, z$ 軸方向変位をそ れぞれ $u, v, w$, 各辺での $s$ 軸まわりの曲げモーメン 卜を $M_{n}$ とする. いま, $u, v, w$ は要素間で連続で幾 何学的境界条件を満たす変位, $M_{n}$ は要素間で連続かつ 力学的境界条件を満たす曲げモーメントとするならば, 各辺での法線方向勾配（以後たわみ角とよぶ） $w_{, n} \equiv \partial w$ / $\partial n$ の要素間での不連続を許した，いわゆる Herrmann の原理 ${ }^{14)}$ に対する Hellinger-Reissner 原理の汎関数 $\Pi_{R}$ は全要素に対して次式で表わされる14),15) :

$$
\Pi_{R}=\sum^{\text {全要素 }} \Pi_{R}^{e}
$$

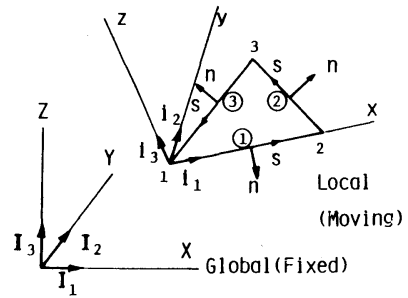

Fig. 1 Coordinate Systems.

$$
\begin{aligned}
& \Pi_{R}^{e}=\iint_{A e}\left[-B\left(N_{i j}, M_{i j}\right)+M_{x, x}+M_{x y, y}\right) w_{, x} \\
& +\left(M_{x y, x}+M_{y, y}\right) w_{, y}+N_{x}\left(u_{, x}+1 / 2 w_{, x}^{2}\right) \\
& +N_{y}\left(v_{, y}+1 / 2 w_{, y}^{2}\right)+N_{x y}\left(u, y+v_{, x}+w_{, x} w_{, y}\right) \\
& -\bar{q} w] d A-\oint_{c e} M_{n s} w_{, s} d s-\int_{c_{o} e}\left[\bar{N}_{x n} u+\bar{N}_{y n} v\right. \\
& \left.+\bar{V}_{n} w\right] d s-\int_{C_{u} e} M_{n} \bar{w}_{n} d s
\end{aligned}
$$

ここに, $\Sigma=$ 全要素についての和; $A_{e}=$ 要素面積 $; C^{e}=$ 要素全周; $C_{\sigma}^{e}=$ 要素周辺のうち, 力学的境界に含まれる 部分; $C_{u}^{e}=$ 要素周辺のうち，幾何学的境界に含まれる 部分; $B\left(N_{i j}, M_{i j}\right)=$ 要素のコンプリメンタリーエネル ギ一密度関数; $N_{x}, N_{y}, N_{x y}=x, y$ 方向膜力, せん断 力; $M_{x}, M_{y}, M_{x y}=x, y$ 断面曲げモーメント,ねじりモー メント; $M_{n s}$ =要素辺の内向き法線 $(-n$ 軸) まわりの ねじりモーメント; $\bar{q}, \bar{N}_{x n}, \bar{N}_{y n}, \bar{V}_{n}=z$ 軸方向分布 外力, 力学的境界に作用する $x, y$ 方向面内力, $z$ 軸方 向面外力; $\bar{w}_{n}=$ 幾何学的境界での規定たわみ角, を表 わす。

次に式 (2) の増分形を初期応力問題 ${ }^{4)}$ として求める. 既知の応力状態すなわち初期応力状態 (状態 $(0)$ ) で, 要素は完全に平らな板で近似できる（仮定@）とし，

Fig. 1 の $(x, y, z)$ を移動座標系とし, この座標系で増 分変形量を記述する．いま，荷重または強制変位が変化 することにより初期応力状態からそれに近接する変形状 態 (状態 $(1))$ に移動したとすると, $\Pi_{R}^{e}$ の変化量 $\Delta \Pi_{R}^{e}$ は初期応力状態で要素が完全に平らであることより式 （2）の諸量で, 変形量 $(u, v, w)$ は増分量その他の 量は初期応力状態の量と増分量の和と置くことにより次 式を得る：

$$
\begin{aligned}
& \Delta \Pi_{R}^{e}=\Delta \Pi_{R 1}^{e}+\Delta \Pi_{R 2}^{e} \\
& \Delta \Pi_{R 1}^{e}=\iint_{A e}\left[\left\{\left(M_{x}+\Delta M_{x}\right)_{, x}+\left(M_{x y}+\Delta M_{x y}\right)_{y}\right\} \Delta w_{, x}\right. \\
& +\left\{\left(M_{x y}+\Delta M_{x y}\right)_{, x}+\left(M_{y}+\Delta M_{y}\right)_{, y}\right\} \Delta w_{, y} \\
& -(\bar{q}+\Delta \bar{q}) \Delta w] d A-\oint_{c e}\left(M_{n s}+\Delta M_{n s}\right) \Delta w_{, s} d s \\
& -\oint_{c_{o} e}\left(\bar{V}_{n}+\Delta \bar{V}_{n}\right) \Delta w d s-\int_{c^{e}} \Delta M_{n}\left(\bar{w}_{, n}+\Delta \bar{w}_{n}\right) d s
\end{aligned}
$$

$$
\begin{aligned}
\Delta \Pi_{R 2}^{e} & =\iint_{A_{e}}\left[\left(N_{x}+\Delta N_{x}\right)\left(\Delta u_{, x}+1 / 2 \Delta w_{, x}^{2}\right)\right. \\
& +\left(N_{y}+\Delta N_{y}\right)\left(\Delta v_{, y}+1 / 2 \Delta w_{, y}^{2}\right) \\
& +\left(N_{x y}+\Delta N_{x y}\right)\left(\Delta u_{, y}+\Delta v_{, x}+\Delta w_{, x} \Delta w_{, y}\right) \\
& \left.-\Delta B\left(\Delta N_{i j}, \Delta M_{i j} ; N_{i j}, M_{i j}\right)\right] d A \\
& -\int_{c_{e} e}\left[\left(\bar{N}_{x n}+\Delta \bar{N}_{x n}\right) \Delta u+\left(\bar{N}_{y n}+\Delta \bar{N}_{y n}\right) \Delta v\right] d s
\end{aligned}
$$

ここに, $\Delta$ の付いた量は増分量， $\Delta$ の付いてない量は 初期応力状態での量を表わす. 式（4）の最終項には 
$M_{n}\left(\bar{w}_{, n}+\Delta \bar{w}_{n}\right)$ の項があるべきだが，変分を受けると零 となるため省略してある.

増分変位 $\Delta u, \Delta v, \Delta w$ を要素内で線形変化, 増分曲 げモーメント，ねじりモーメント $\Delta M_{x}, \Delta M_{y}, \Delta M_{x y}$ を 要素内で一定と仮定すれば, 式（3）は次式のようにマ トリックス表示できる（右肩の $T$ は転置行列を示す）:

$$
\begin{aligned}
\Delta \Pi_{R}^{e}= & 1 / 2\left(\Delta \boldsymbol{u}_{p}^{T} \boldsymbol{k}_{11} \Delta \boldsymbol{u}_{p}+\Delta \boldsymbol{w}^{T} \boldsymbol{k}_{22} \Delta \boldsymbol{w}+\Delta \boldsymbol{M}_{n}^{T} \boldsymbol{k}_{33} \Delta \boldsymbol{M}_{n}\right) \\
& +\Delta \boldsymbol{u}_{\rho}^{T} \boldsymbol{k}_{13} \Delta \boldsymbol{M}_{n}+\Delta \boldsymbol{w}^{T} \boldsymbol{k}_{23} \Delta \boldsymbol{M}_{n} \\
& -\Delta \boldsymbol{u}_{p}^{T}\left(\Delta \overline{\boldsymbol{p}}_{p}+\overline{\boldsymbol{p}}_{p}-\boldsymbol{p}^{*}\right)-\Delta \boldsymbol{w}^{T}\left(\Delta \overline{\boldsymbol{q}}+\overline{\boldsymbol{q}}-\boldsymbol{q}^{*}\right) \\
& -\Delta \boldsymbol{M}_{n}^{T}\left(\Delta \overline{\boldsymbol{\theta}}+\overline{\boldsymbol{\theta}}-\boldsymbol{\theta}^{*}\right) \cdots \ldots \ldots \ldots \ldots \ldots \ldots \ldots(6)
\end{aligned}
$$

上式の誘導および記号は Appendix I および【に示して ある.上式で変分を受ける量は $\Delta \boldsymbol{u}_{p}, \Delta \boldsymbol{w}$ および $\Delta \boldsymbol{M}_{n}$ である. 式（6）の停留条件より次式で表わされる要素 の“接線剛性方程式”を得る：

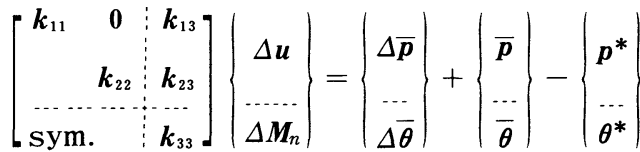

ここで, $\Delta \boldsymbol{u}^{T}=\left[\Delta \boldsymbol{u}_{\rho}^{T}, \Delta \boldsymbol{w}^{T}\right]=$ 節点変位増分 $; \Delta \overline{\boldsymbol{p}}^{T}=\left[\Delta \overline{\boldsymbol{p}}_{\rho}^{T}\right.$, $\left.\Delta \overline{\boldsymbol{q}}^{T}\right]=$ 節点力増分 $; \overline{\boldsymbol{p}}^{T}=\left[\overline{\boldsymbol{p}}_{\boldsymbol{p}}^{T}, \overline{\boldsymbol{q}}^{T}\right]=$ 初期応力状態での節 点力; $\boldsymbol{p}^{* T}=\left[\boldsymbol{p}_{p}^{* T}, \boldsymbol{q}^{* T}\right]=$ 初期応力状態での応力場から 求められる等価節点力; $\Delta \boldsymbol{M}_{n}=$ 節辺曲げモーメント増分 ; $\Delta \overline{\boldsymbol{\theta}}=$ 節辺の規定たわみ角増分 $; \overline{\boldsymbol{\theta}}=$ 初期応力状態での 節辺の規定たわみ角; $\boldsymbol{\theta}^{*}=$ 初期応力状態での曲率から求 められる等価節点たわみ角である. 式 (7) の未知量は 変位増分と曲げモーメント増分で, 係数行列は剛性行列 ではないが，ここでは便宜上“接線剛性方程式”とよぶ. 式 $(7)$ を全要素について求め, 全体座標系に座標変換 した後に重ね合わせ,境界条件の処理をすることにより， 構造物全体の接線剛性方程式が求まる。すなわち,

$$
[\boldsymbol{K}]\left\{\begin{array}{c}
\Delta \boldsymbol{U} \\
\Delta \boldsymbol{m}_{n}
\end{array}\right\}=\left\{\begin{array}{c}
\Delta \overline{\boldsymbol{P}} \\
\Delta \overline{\boldsymbol{\theta}}
\end{array}\right\}+\left\{\begin{array}{l}
\overline{\boldsymbol{P}} \\
\overline{\boldsymbol{\theta}}
\end{array}\right\}-\left\{\begin{array}{l}
\boldsymbol{P}^{*} \\
\boldsymbol{\theta}^{*}
\end{array}\right\}
$$

ここに, $K=$ 構造物全体の接線剛性行列, $\Delta \boldsymbol{U}, \Delta \boldsymbol{m}_{n}$, $\Delta \bar{P} \cdots \boldsymbol{\theta}^{*}$ はそれぞれ $\Delta \boldsymbol{u}, \Delta \boldsymbol{M}_{n}, \Delta \bar{p} \cdots \theta^{*}$ に対応する構 造物全体の量である. 局所座標から全体座標への座標変 換行列はたとえば文献 15）pp.139～141 に与えられて いる. 式（８）の右辺項 $\Delta \overline{\boldsymbol{P}}+\overline{\boldsymbol{P}}-\boldsymbol{P}^{*}$ は節点における 不つり合い力項で通常の変位法における解法と同じであ る. 混合法では $\Delta \overline{\boldsymbol{\theta}}+\overline{\boldsymbol{\theta}}-\boldsymbol{\theta}^{*}$ の項があるが，これは節 辺に生ずるたわみ角の不連続性を表わす項である.

\section{（3）数値計算方法}

数值計算は式（８）の右辺項が零になるまで NewtonRaphson 法に従い繰り返し計算を行う。ただし，本解 析では変位増分法を用いたので， $\Delta \overline{\boldsymbol{P}}$ には荷重増分の代 わりに, 既知 (強制) 変位増分に関連する項が入ること となる.式（８）の連立方程式は帯行列に対する Gauss
の消去法を用いて解いた. 以下，数値計算に必要な手法 の概要を述べる。

a) ひずみ増分，応力増分

各要素の節点変位増分 $\Delta \boldsymbol{u}$, 節辺曲げモーメント増分 $\Delta \boldsymbol{M}_{n}$ が既知のとき, 要素内のひずみ増分, 応力増分を 求める方法について述べる. 要素の中央面ひずみ増分は, 新しい変形状態（状態（1））での要素座標系の節点座 標から，元の変形状態 (状態 $(0))$ の要素座標系の節 点座標を差し引き, 要素の剛体変位成分を除去した節点 変位増分を求め,ひずみ増分-変位増分関係の線形項 (式 $(\mathrm{A} \cdot 3),(\mathrm{A} \cdot 34)$ の $\left.\Delta \boldsymbol{e}_{L}\right)$ のみから求める.いま $\left(x_{i}^{(0)}, y_{i}^{(0)}\right)$, $\left(x_{i}^{(1)}, y_{i}^{(1)}\right)(i=1,2,3)$ をそれぞれ節点 $i$ の $(0),(1)$ 状態での $(x, y)$ 座標とすれば, Fig. 1 の要素について, 変形後の座標で測った, 剛体変位を除去した変位増分は,

$$
\Delta \boldsymbol{u}_{\rho}^{T}=\left[0, x_{2}^{(1)}-x_{2}^{(0)}, x_{3}^{(1)}-x_{3}^{(0)}, 0,0, y_{3}^{(1)}-y_{3}^{(0)}\right] \cdots \cdots(9)
$$
で表わされる。したがって，ひずみ増分は式 $(\mathrm{A} \cdot 34)$, (A·32) より求められる. 要素内の曲げモーメント増分 $\Delta \boldsymbol{M}$ は， $\Delta \boldsymbol{M}_{n}$ を式 $(\mathrm{A} \cdot 17)$ に代入すれば求められる. ここで $\Delta \boldsymbol{M}$ は式 $(\mathrm{A} \cdot 2)$ に定義されている. 要素内の $\Delta \boldsymbol{e}_{L}, \Delta \boldsymbol{M}$ が求まれば, 構成則 (式 $\left.(\mathrm{A} \cdot 36)\right)$ より, 膜 力増分 $\Delta \boldsymbol{N}$, 曲率増分 $\Delta \boldsymbol{x}$ (式 $(\mathrm{A} \cdot 2))$ が求まり, 要素 内任意点のひずみ増分 $\Delta \tilde{\boldsymbol{e}}$, 応力増分 $\Delta \tilde{\boldsymbol{\sigma}}$ は, それぞれ, 式 $(\mathrm{A} \cdot 20)$ で $\Delta \boldsymbol{e} \cong \Delta \boldsymbol{e}_{L}$ と置いた式，および式 $(\mathrm{A} \cdot 35)$ より求められる.なお，弾性域から塑性域へ移行する要 素の構成則の取り扱い方法，および降伏曲面をはずれた 点を降伏曲面に戻す操作は文献 16）pp. 249～257 の手 法を用い，後者についてはそのうち “refined process for reducing a stress point to the yield surface” を用い た.

b ）等価節点力 $\boldsymbol{p}^{*}$, 等価たわみ角 $\theta^{*}$

上で求められた $\Delta \boldsymbol{N}, \Delta \boldsymbol{M}_{n}, \Delta \boldsymbol{x}$ を状態（０）の対応 する量に加え，状態（1）での量 $N, M_{n}, \boldsymbol{x}$ を求め, それぞれ, 式 $(\mathrm{A} \cdot 30),(\mathrm{A} \cdot 11),(\mathrm{A} \cdot 31)$ に代入すれば, $p^{* T}=\left[p_{p}^{* T}, q^{* T}\right], \theta^{*}$ は求められる.

c ）節辺の規定たわみ角 $\Delta \bar{\theta}, \bar{\theta}, \Delta \overline{\boldsymbol{\theta}}, \overline{\boldsymbol{\theta}}$

混合法における変位場は, 要素間節辺または法線方向 勾配が規定された幾何学的境界で，法線方向勾配（たわ み角）の連続性が要求されていないため, 変形が進むに つれて変位場から得られる変形形状は要素間または幾何 学的境界で要素が折れ曲がり，たわみ角の不連続が生す る. 状態 $(0)$ におけるこの折れ曲がり角度が $\overline{\boldsymbol{\theta}}$ になる. 一方 $\Delta \overline{\boldsymbol{\theta}}$ は要素間で零と置いてよく，また，本解析で は幾何学的境界において規定されたたわみ角は零として いる(固定端)ので, $\Delta \overline{\boldsymbol{\theta}}$ または $\Delta \bar{\theta}$ は考えなくてもよい. 結局, $\overline{\boldsymbol{\theta}}$ の各要素節辺での值を求める必要があるが, これは次のような幾何学的考察から求めることができる (Fig. 1，2 参照)。要素節辺®の単位法線ベクトルを $\boldsymbol{n}_{\kappa}$ 


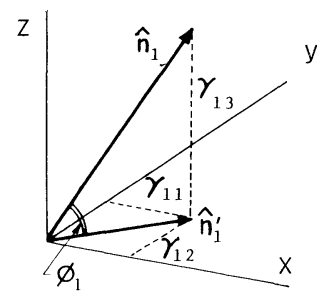

Fig. 2 Definition of $\phi_{1}$ and $\gamma_{1 m}$.

$(k=1,2,3)$, 局所座標系 $(x, y, z)$ 方向の単位基底べ クトルを $\boldsymbol{i}_{i}(i=1,2,3 ; x=1, y=2, z=3)$ とし, 無載 荷状態（後述の初期たわみを板要素に与えた状態）での 対応する量に記号へを上に付け， $\hat{\boldsymbol{n}}_{k}, \hat{\boldsymbol{i}}_{i}$ などのように表 わす. いま, 全体座標系 $(X, Y, Z)$ の単位基底べクト ルを $\boldsymbol{I}_{j}(j=1,2,3 ; X=1, Y=2, Z=3)$ とすれば, 次 式が成り立つ.

$$
\hat{\boldsymbol{n}}_{k}=\sum_{i=1}^{3} \sum_{j=1}^{3} \hat{l}_{k i} \hat{l}_{i j} \boldsymbol{I}_{\boldsymbol{j}}, \quad \boldsymbol{i}_{m}=\sum_{n=1}^{3} l_{m n} \boldsymbol{I}_{n}
$$

ここに, $\hat{l}_{k i}^{\prime}$ は $\hat{\boldsymbol{n}}_{k}$ の局所座標系 $(\hat{x}, \hat{y}, \hat{z})$ における方 向余弦, $\hat{l}_{i j}, l_{m n}$ は, それぞれ, $\hat{\boldsymbol{i}}_{i}, \boldsymbol{i}_{i}$ の全体座標系に おける方向余弦で具体的な形はたとえば文献 15）の pp. 139〜141に与えられている. $l_{m n}$ を成分とする行列 $\left[l_{m n}\right]$ は直交行列であることを考慮すれば，式 $(10)$ よ り次式が得られる.

$$
\hat{\boldsymbol{n}}_{k}=\sum_{m=1}^{3} \gamma_{k m} i_{m}, \quad \gamma_{k m}=\sum_{i=1}^{3} \sum_{j=1}^{3} \hat{l}_{k i}^{\prime} \hat{l}_{i j} l_{m j}
$$

したがって, ベクトル $\hat{\boldsymbol{n}}_{k}$ とベクトル $\hat{\boldsymbol{n}}_{k}$ を $(x, y)$ 平 面に射影したベクトル $\hat{\boldsymbol{n}}_{k}^{\prime}$ のなす角度 $\phi_{k}(k=1,2,3)$ は,

$$
\tan \phi_{k}=\gamma_{k 3} / \sqrt{\gamma_{k 1}^{2}+\gamma_{k 2}^{2}} \text {. }
$$

で表わされる.この $\phi_{k}$ が初期応力状態 $(0)$ での規定 勾配ベクトル $\overline{\boldsymbol{w}}_{n}^{T}($ 式 $(\mathrm{A} \cdot 1))$ の成分となり, $\overline{\boldsymbol{\theta}}$ は定義 式 $(A \cdot 10),(A \cdot 16)$ より次式で与えられる.

$\overline{\boldsymbol{\theta}}^{T}=\left[a_{1} \phi_{1}, a_{2} \phi_{2}, a_{3} \phi_{3}\right]$

\section{d）初期不整量の導入}

初期不整として構成板要素の初期たわみと溶接による 残留応力を同時に考慮する. 初期たわみを有する構成板 要素は平面三角形要素の集合と考え, 残留応力は要素内 で一定と考える. 初期たわみ, 残留応力の具体的な形は 後述する.このように両初期不整を同時に考慮した場合, 無載荷状態で要素の節点に不つり合い力が生ずる ${ }^{5)}$.こ れを解消するため, 無載荷状態で各節点に次式で求まる 仮想外力 $\overline{\boldsymbol{P}}_{I}$ を作用させる.

$$
\overline{\boldsymbol{P}}_{I}=\boldsymbol{P}_{r}^{*}
$$

ここに，P草は構造物の形状として初期たわみを与えた 形状を用い, 応力状態として残留応力のみを用いて算出 した等価節点力 $\boldsymbol{P}^{*}$ である.

\section{3. 短柱の $\boldsymbol{M}-\boldsymbol{P}-\boldsymbol{\Phi}$ 曲線の数値計算方法}

前節の一般的解析法を用い短柱の $M-P-\Phi$ 曲線を解 析する手法について述べる. 短柱断面は少なくとも 1 軸 対称とし, 端モーメント $M$ は対称面内に作用するもの とする．計算は一定軸方向圧縮力 $P$ のもとで漸増する 端モーメント $M$ に対応する短柱の平均曲率 $\Phi$ を求める ことにある. そのために, Fig.3(a) に示すように, 部 材端に $Y$ 軸方向に線形的に変化する強制軸方向変位 (以 下強制変位という）を与え，それによって生ずる部材端 での節点の軸方向反力 (以下単に反力という) より軸力, 端モーメントを求め, 軸力が所定の值 $P$ になるまで強 制変位を修正する。部材の平均曲率は部材端部に与えた 強制変位の勾配 $\varphi_{r}$ より次式を用いて計算することがで きる.

$$
\Phi=2 \varphi_{T} / l \text {. }
$$

ここに, $l$ は短柱の部材長である. 軸力を与えられた值 $P$ に収束させるための数值計算方法は以下に示すとお りである (Fig.3(b)，(c) 参照).ここで, 状態 (0) での軸力が $P$ に収束しており, 端モーメント $M_{0}$, 曲率 $\Phi_{0}$ が既知であるとする.

(a) 部材端に断面の重心軸まわりの微小回転 $\Delta \varphi$ に よって生ずる強制変位増分 $\Delta \bar{U}$ を与える.

(b) 変位増分後の状態（状態（1）とする）での反力 $\boldsymbol{F}^{(1)}$ (引張力を正とする）を求める.

(c) 反力 $\boldsymbol{F}^{(1)}$ より軸力 $P^{(1)}$, 端モーメント $\boldsymbol{M}^{(1)}$ を求め る.このとき， $P^{(1)} \cong P$ ならば $M^{(1)}$ を端モーメント の収束値 $M_{0}$ とし, 対応する曲率は $\Phi_{0}+2 \Delta \varphi / l$ よ り求める. 収束しないときは次のステップにゆく.

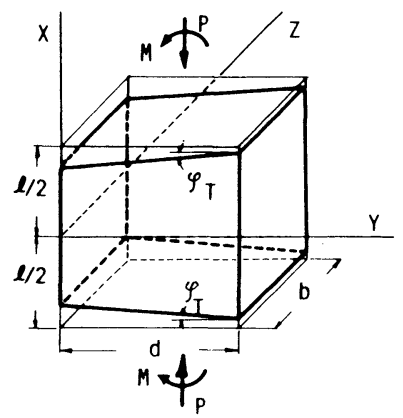

(a)

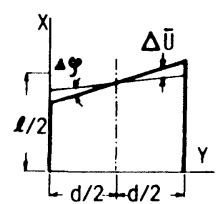

(b)

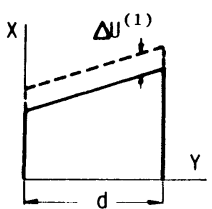

(c)
Fig. 3 Procedures to Compute $M-P-\Phi$ Curves. 
(d) 強制変位増分 $\Delta \bar{U}$ の修正值 $\Delta U^{(1)}(Y$ 方向に一定 とする) を次式より求める.

$$
\Delta U^{(1)}=-\left(P-P^{(1)}\right) / \Sigma \Delta F_{u}
$$

ここに, $\Sigma=$ 端部断面節点についての総和, $\Delta F_{u}=$ 一椂単位強制変位増分 (Fig. 3(c) で $\Delta U^{(1)}=1.0$ と おいた変位増分）を状態（1）に与えたときの反力 増分である. 式 (16) は状態 (1) での軸力 $P^{(1)}$ と 軸力増分 $-\Delta U^{(1)} \Sigma \Delta F_{u}$ の和が $P$ に等しくなる条件 から求められる.

(e) $\Delta \bar{U}$ に修正值 $\Delta U^{(1)}$ を加えた新しい強制変位増分 を $\Delta \bar{U}$ とし, (b一@eの過程を繰り返す.

上記の計算過程では 2 か所で収束判定が必要であり, 次のように行った.

\section{ステップ(b)゙の収束判定}

次のいずれの条件も満足するとき，解は収束したとみ なす。

(1) $\|\Delta \boldsymbol{U}\| \leqq \epsilon_{1}\|\Sigma \Delta \boldsymbol{U}\|$

(2) $\left\|\Delta \boldsymbol{m}_{n}\right\| \leqq \epsilon_{2}\left\|\Sigma \Delta \boldsymbol{m}_{n}\right\|$

(3) $\left\|\Delta \overline{\boldsymbol{P}}+\overline{\boldsymbol{P}}-\boldsymbol{P}^{*}\right\| \leqq \epsilon_{3}\|\Delta \boldsymbol{F}\|$

ここに, $\|\cdot\|=$ ユークリッドノルム, $\Sigma$ =反復計算中 の総和, $\Delta \boldsymbol{F}=$ 強制変位増分 $\Delta \bar{U}$ によって生ずる反力増 分である. 数値計算では $\epsilon_{1}=\epsilon_{2}=\epsilon_{3}=0.01$ を用いた.

ステップ(d)での収束判定

(4) $\left|P-P^{(1)}\right| \leqq \epsilon_{4} P_{Y} \cdots$

ここに， $P_{Y}$ は断面の降伏軸力（断面積 $\times$ 降伏応力）で あり， $\epsilon_{4}=10^{-4}$ を用いた。

\section{4. 数値計算結果}

\section{（1）一様圧縮板}

解析プログラムの精度の確認のため, Fig. 4(a) に示 す圧縮板の解析を行い, 文献 8) の解などと比較する. 境界条件は $Y= \pm b / 2$ で面内変位自由, $X= \pm a / 2$ で

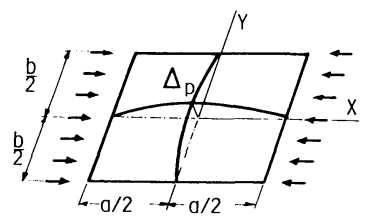

(a) Plate with Initial Deflection

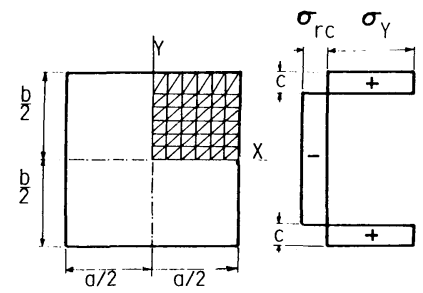

(b) Assumed Residual Stress Pattern and FEM Mesh

Fig. 4
せん断応力が零として一様面内変位を $X$ 方向に与える. 面外変形に対する境界条件は単純支持とする. 残留応力 分布はFig. 4(b) に示す形とし, 片側の引張残留応力部 分の幅 $c$ は, 文献 8$)$ に従い, $c / t=3$ とした. 断面内 で残留応力が自己つり合いにある条件より, 最大圧縮残 留応力 $\sigma_{r c}$ は $\sigma_{r c} / \sigma_{Y}=6 /(b / t-6)$ より求められる.こ こに $\sigma_{Y}$ は降伏応力である. 初期たわみ $W_{0}$ の形状は

$$
W_{0}=\Delta_{\rho} \cos \frac{\pi X}{a} \cos \frac{\pi Y}{b}
$$

とした。ここに， $\Delta_{p}$ は最大初期たわみで, 板幅 $b$ の $1 / 1000$ または $1 / 200$ とした。有限要素分割は Fig. 4(b) に示すように, 幅方向の半分を, 引張残留応力部を 1 分 割, 圧縮残留応力部を 5 分割, 計 6 分割し, 長さ方向の 半分を 6 等分割した. 計算に用いた入力デー夕は, 弾性 係数 $E=205 \mathrm{GPa}$, 降伏応力 $\sigma_{Y}=250 \mathrm{MPa}$, 板厚 $t=8$ $\mathrm{mm}$, ポアンン比 $\nu=0.3$, アスペクト比 $a / b=0.875$, 幅厚比 $b / t=30,40,55,80$ である. なお，これらの 幅厚比を次式で定義される幅厚比パラメーターで表わす と，それぞれ，0.551，0.735，1.01，1.47 となる.

$$
R=\frac{b}{t} \sqrt{\frac{\sigma_{Y}}{E} \frac{12\left(1-\nu^{2}\right)}{\pi^{2} k}}
$$

ここで， $k=$ 座屈係数で 4.0 を用いた.

縦軸に平均応力 $\sigma_{a}$ 之降伏応力 $\sigma_{\mathrm{Y}}$ の比, 横軸に平均ひ ずみ $\varepsilon_{a}$ と降伏ひずみ $\varepsilon_{Y}$ の比で表わした結果を Moxham および Little の結果 ${ }^{8), 17), 18)}$ ともに Fig. 5 に示す. 平均 応力は載荷辺での反力の総和を断面積 $b t$ で除した量, 平均ひずみは載荷辺の相対的な $X$ 軸方向変位を長さ $a$ で除した量である．Little の解 ${ }^{18}$ は，文献 9）によれば 最も正確な解といわれ，文献 8）に示されている6 種類 の解のほぼ中間あたりに位置する. Moxham の解は全 般的に Little の解の上側にあるが, 幅厚比の小さい板

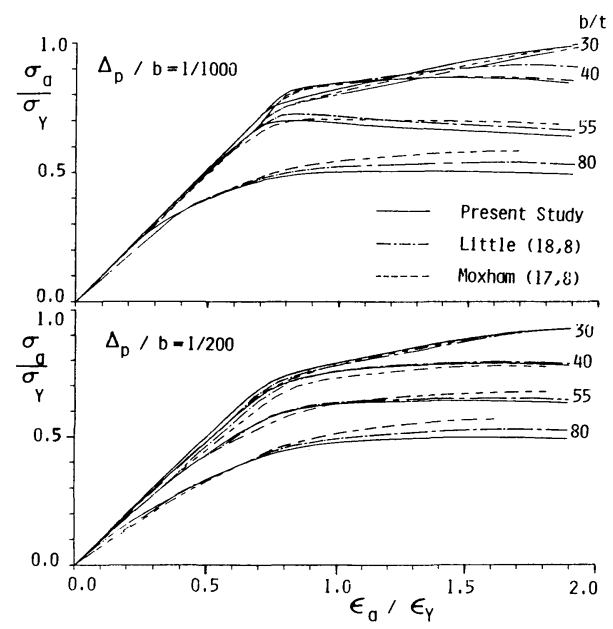

Fig. 5 Average Stress-Average Strain Curves of Single Plates. 


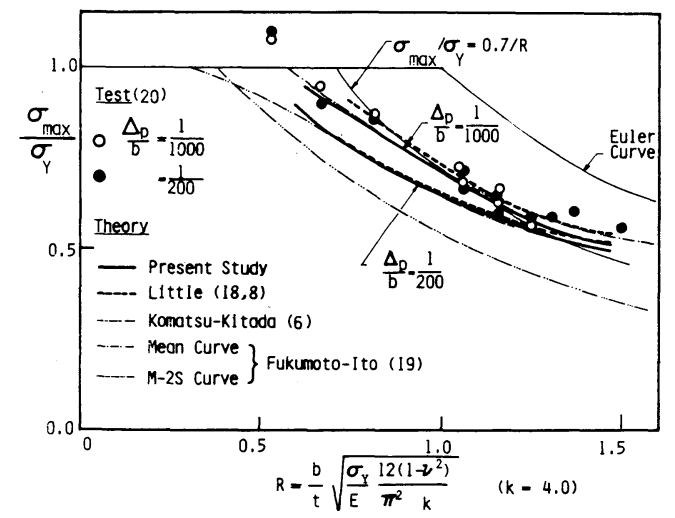

Fig. 6 Comparison of Maximum Strengths of Single Plates.

に対しては下側にある場合もある. 本解析結果は, すべ てのケースについて, Little の解を多少下回る位置にあ るがその差はあまり大きくないことがわかり, 本解析が 十分信頼できるものと判断できる. 次にこれらの図から 各曲線のピークすなわち極限平均応力 $\sigma_{\max } / \sigma_{Y}$ を求め, 幅厚比パラメーターRに対してプロットし, Little の 解析結果, 小松・北田の耐荷力曲線6), 福本・伊藤のデー タベースより得られた耐荷力曲線 ${ }^{19)}$ ，および Bradfield の実験結果 ${ }^{20)}$ と比較したものが Fig. 6 である. 小松・北 田の曲線は $\sigma_{r c} / \sigma_{Y}=0.4, \Delta_{\rho} / b=1 / 150$ として計算され たものであり, 福本 ・伊藤の曲線は 383 個の実験より得 られた耐荷力の平均值および平均値一2・標準偏差を表 わす曲線である. Bradfield の実験は供試体に $\Delta_{\rho} / b=$ $1 / 1000$ または $1 / 200$ の初期たわみを強制的に付け，入 熱量を制御した溶接ビードを非載荷辺に盛った一枚板を 用いて行われたものである. 残留応力の実測デー夕によ

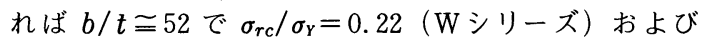
$\sigma_{r c} / \sigma_{Y}=0.076$ ( L シリーズ ) であり, 残留応力の自己 つり合い条件より $c / t$ を求めると, それぞれ, 4.7 お よび 1.84 となり, 計算で用いた值はこれらの中間にあ ることがわかる. 実験結果は残留応力の大きさによる強 度の有意な差はみられないので, 初期たわみの大きさの みを区別してプロットしてある.この図より次のことが わかる：(1)本解析結果は $\Delta_{\rho} / b=1 / 200$ のとき, Little の解とほとんど一致し， $\Delta_{p} / b=1 / 1000$ のときには多少 低めの位置にある，(2)初期たわみが $b / 1000$ から $b / 200$ に変化することによる強度の低下は高々 $10 \%$ 程度であ り，幅厚比が大きくなるにつれて小さくなる，(3)初期た わみが $b / 1000$ の実験結果は本解析結果とよく一致する ものの, $b / 200$ の実験結果は解析結果を上回り,むしろ $b / 1000$ の解析結果よよく一致する，(4)初期たわみが $b / 1000$ の本解析結果は, 福本 ・伊藤の平均耐荷力曲線 とほとんど一致する, (5)小松・北田の曲線は $\Delta_{p}=$ $b / 200$ の本解析結果とほとんど一致する.

\section{（2）曲げと圧縮を受ける箱形断面短柱}

\section{計算データ}

Fig. 7(a) に示すような曲げと圧縮を受ける箱形断面 短柱（フランジ幅 $=b$, ウェブ幅 $=d$, 板厚 $=t$, 長さ $=l)$ を考え, 対称性から，1/4の部分を解析の対象と した. 載荷辺 $(X=l / 2)$ は単純支持で面内女ん断力が 零として強制面内変位を $X$ 軸方向に与える. 初期たわ み形状は, Fig.7(b) に示すように, 各板要素に式 (19) で表わされる初期たわみを仮定した。ただし，フランジ 部分の初期たわみは断面の内側に, ウェブ部分は外側に 仮定し, フランジとウェブの境界は直角を保つように仮 定した。したがって, フランジ板とウェブ板の最大初期 たわみ（それぞれ $\Delta_{f}$ と $\Delta_{w}$ と記す）には $\Delta_{f} / b=\Delta_{w} / d$ の関係がある. 残留応力は Fig. 4(b) に示す分布形を各 板要素に与え, 分割方法は Fig. 7(a) に示すように, 各 フランジを $6 \times 6$, ウェブを $12 \times 6$ 分割した. 計算の対 象とした短柱は著者らが実験した ${ }^{21}$ 正方形および長方形 $(d / b=0.75)$ 箱形断面で計算に用いたデー夕は：材質 $=\mathrm{SM} 58 ; E=210 \mathrm{GPa} ; \sigma_{\mathrm{Y}}=568 \mathrm{MPa} ; t=4.5 \mathrm{~mm} ; \nu$ $=0.3 ; d / b=1.0,0.75 ; b / t=29,44,58 \quad\left(R_{f}=0.79\right.$, $1: 20,1.59) ; \sigma_{r c} / \sigma_{\mathrm{Y}}=0.3,0.2,0.15(b / t=29,44$, 58 に対して $) ; \Delta_{f} / b=\Delta_{w} / d=1 / 400$ である.ただし， $R_{f}$ はフランジ板の幅厚比パラメーター $(k=4.0)$ であ る.

\section{アスペクト比 $l / b$ の決定}

短柱の挙動は構成板要素のアスペクト比 $l / b$ によっ て変動すると考えられ, 安全側をみて, 最小の強度を与

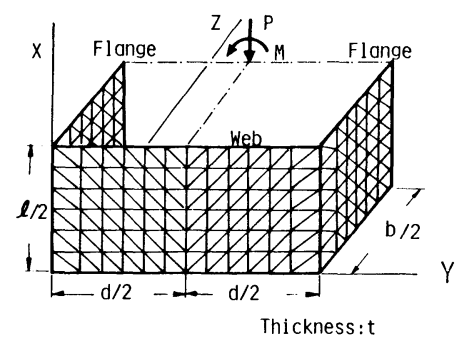

(a) FEM Mesh in Box Column Analysis

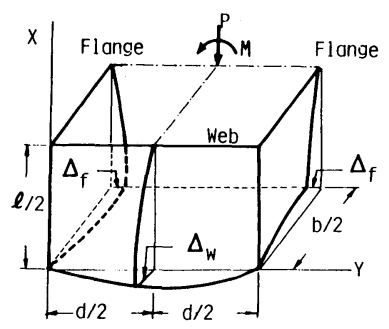

(b) Box Column with Initial Deflection

Fig. 7 
えるアスペクト比で解析するのがよいと考えられる. 前 節の純圧縮板に対しては, Moxham ${ }^{17)}$ はアスペクト比 $a / b=0.875$ で最小の強度が得られるとしているが, 小 松・北田 ${ }^{6)}$ は幅厚比の大きさによって $a / b=0.5 \sim 1.0$ と 変化することを示している.このアスペクト比は, 初期 不整の大きさにも依存するといわれているが8)，いずれ にしても $a / b$ の変化に対し強度はあまり敏感ではない. 圧縮と曲げを受ける短柱では, 幅厚比, 初期不整以外に, 荷重条件 ( $P$ と $M$ の比), 断面形状 $(d / b$ 比) によっ ても最小の強度を与えるアスペクト比 (以後 $(l / b)_{0}$ と 書く）は異なると考えられ, 厳密に $(l / b)_{0}$ を定めるこ とは大変な数値計算を必要とする. そこで, ここでは, 初期不整のない理想短柱の弾性座屈解析から求められた $(l / b)_{0}$ を参考に，2，3 の極限強度解析のみから $(l / b)_{0}$ を定める. 弾性座屈解析は有限帯板法を用いて行い, 結 果を縦軸に $(l / b)_{0}$, 横軸に応力勾配係数 $\psi=\left(\sigma_{1}-\sigma_{2}\right) / \sigma_{1}$ をとって Fig. 8 に示す.ここに， $\sigma_{1} ， \sigma_{2}$ はそれぞれ最大, 最小圧縮応力である. 一方, 前述の計算データを用い, $b / t=29\left(R_{f}=0.79\right)$ で $P / P_{Y} \cong 0.5$, および $b / t=58\left(R_{f}\right.$ =1.59) で $P / P_{Y}=0.0$ (純曲げ) のもとで数種類のア スペクト比を与えて弾塑性有限変位解析を行い, $(l / b)_{0}$ の值を求め, $\phi$ に対して Fig. 8 にプロットした. ただし, $P / P_{Y}=0.5$ に対する $\phi$ の值は $P / P_{Y}=0.5$ および $(l / b)_{0}$ に対応する $M-P-\Phi$ 曲線のピークの值 $M_{\max }$ より弾性応 力分布を仮定して求めた. 有限変位解析より得られた $\psi$ $=0$ (純圧縮) での $(l / b)_{0}$ の值は, 前述の Moxham の 結果をプロットしたものである. 有限変位解析より得ら れた $(l / b)_{0}$ の值は, 弾性座屈解析より得られた值の 76 〜 $88 \%$ であることが図よりわかる. 純圧縮板に対する 小松・北田 ${ }^{6)}$ の計算によれば, $R=0.7,1.3$ の単独圧縮 板に対しアスペクト比が 0.7 から 1.0 に変化しても強度 の変化は高々数％であること, および本解析から得ら

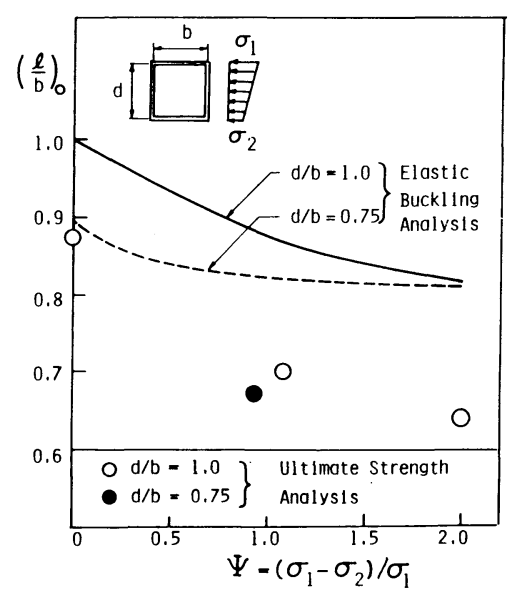

Fig. 8 Aspect Ratio giving the Minimum Strength.
れた短柱の極限強度の変化もアスペクト比の変化に対し 上と同様の鈍感さであったことより，本解析では，すべ て， $\underline{\underline{l} / b=0.7}$ を用いることにした.

\section{$M-P-\Phi$ 曲線}

前述のデータを用い 5 種類の短柱 $(b / t=29$ の短柱 については $d / b=0.75$ の断面のみ）について $M-P-\Phi$ 曲線を計算した。計算はあらかじめ純圧縮について極限 軸方向圧縮力を求めておき, それに至るまでの軸力 $P$ を $P_{Y}$ の 0.1 きざみごとに与えていった. 得られた結果 の一部を Fig. 9 に示す.ここで， $M_{Y}$ は局部座屈を考え ないで求めた断面の降伏モーメント， $\Phi_{Y}$ は $M_{Y}$ に対応 する降伏時の曲率である．いずれのケースについても軸 力 $P$ が大きくなるにつれ局部座屈の影響が顕著に現わ れ, しかも, 断面形状の差が出てくることがわかる. こ れは，軸力が大きくなるとフランジ板の局部座屈ばかり でなくウェブ板の局部座屈の影響が出てくるためであ る.このことをはっきり示すために, 本解析結果の一部 $\left(b / t=44\right.$ の正方形断面) を Little の方法 ${ }^{4)}$ で求めた結 果と比較することにする (Fig. 10). Little の方法は, フランジ単独板の弾塑性有限変位解析から Fig. 5 に示し たような板要素の平均応力ー平均ひずみ関係をあらかじ め求めておき, それをフランジ板材料の応力ーひずみ関 係とみなして断面の $M-P-\Phi$ 曲線を求める方法であり, ウェブ板の応力ーひずみ関係をフランジ板のそれと同一 とみなして計算した結果が点線 (Web Buckling Considered-WB), 完全弾塑性応力ーひずみ関係を用い て計算した結果が一点鎖線 (No Web Buckling-NWB) である.なお,この短柱の純圧縮強度は $P_{\max } / P_{Y}=$ 0.567 である.この図より, 軸力が $0.2 P_{Y}$ (または $\left.0.35 P_{\max }\right)$ 以下と比較的小さいときには, 近似解 NWB は本解析結果と比較的よく合うが, 軸力が $0.4 P_{Y}$ (または $0.7 P_{\max }$ ) となると, 近似解 WB の方が精度

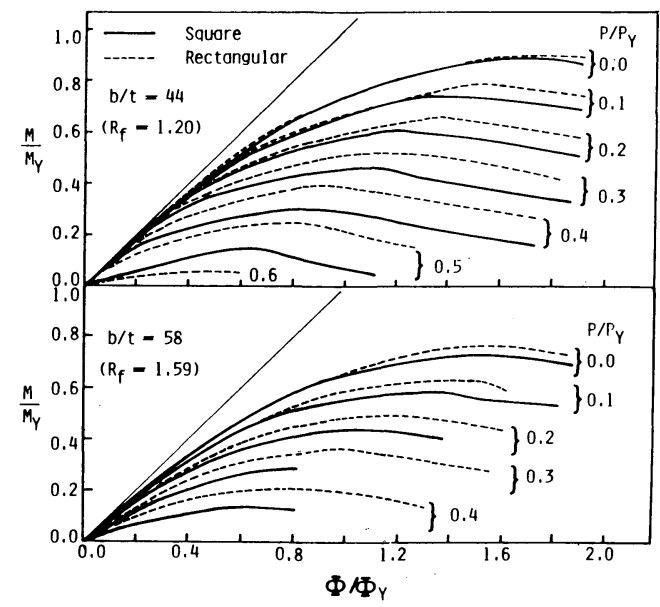

Fig. 9 Computed $\boldsymbol{M}-\boldsymbol{P}-\boldsymbol{\Phi}$ Curves of Box Columns. 


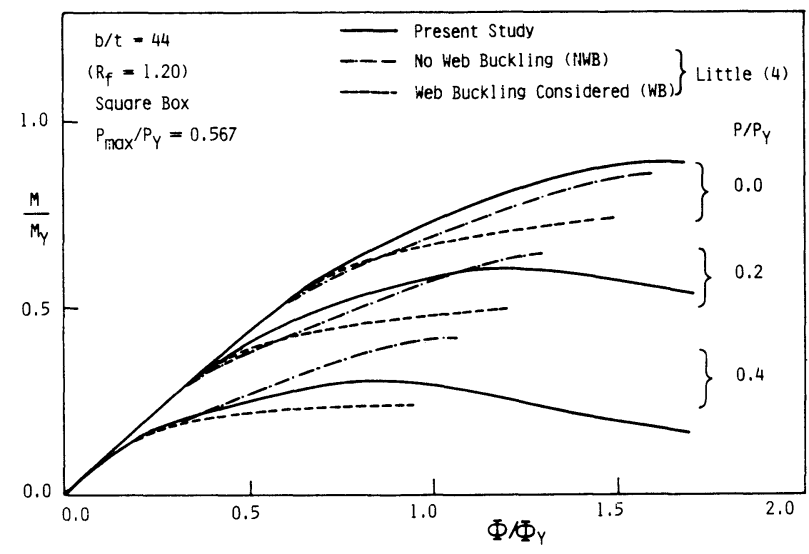

Fig. 10 Comparison of $M-P-\Phi$ Curves Computed by the Present Analysis and Little's Method.

がよくなることがわかる．この事実は当然のことである が, Little の方法は場合によっては相当の誤差を含むこ とになり，軸方向圧縮力が小さいときの NWBによる 解以外，あまり信頼できる解を得ることができない.

これまでの箱形断面の $M-P-\Phi$ 曲線は, フランジ板 の初期たわみが断面の内側に生じていると仮定して求め たものである. 板要素の初期たわみの方向が $M-P-\Phi$ 曲線に与える影響を調べるため, $b / t=44$ の正方形箱 形断面に, $P / P_{Y}=0.2$ の軸力が作用したときの $M-P-$ $\Phi$ 曲線を, 大きさは同一で方向が逆の初期たわみを与 えて計算したが, 差は最大モーメントで $1 \%$ 以下であっ た. したがって, Fig. 9 の結果は, 初期たわみが仮定方 向と逆の場合にも適用できると考えられる.

\section{極限強度の相関公式}

Fig. 9 に示した $M-P-\Phi$ 曲線より曲げと圧縮を受ける 短柱の極限強度を求め, 軸方向圧縮力 $P / P_{Y}$ と曲げモ一 メント $M / M_{Y}$ の相関関係の形でプロットしたものが Fig. 11 である．同図中には，局部座屈を考えないとき の箱形断面（ただし， $b / t=44$ の正方形箱形）の極限

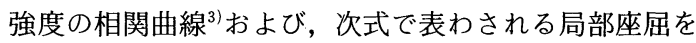
考えた相関曲線もプロットしてある.

$$
\frac{P}{Q P_{Y}}+\frac{M}{M_{u}}=1.0
$$

ここに

$$
\begin{aligned}
& Q=0.737 / R \leqq 1.0 \\
& \frac{M_{u}}{M_{Y}}=\frac{(2+3 / \alpha)\left(0.737 / R_{f}\right)+2+\alpha}{4+\alpha+3 / \alpha} \leqq 1.0
\end{aligned}
$$

$\alpha=d / b$

である. $Q$ は実験より求められる中心軸圧縮短柱の強 度の推定式 ${ }^{2)}$ であり， $R$ は短柱の幅厚比パラメーターで, 式 (20) で, 座屈係数 $k$ に等価座屈係数とよばれる量 ${ }^{1)}$ $k_{e q}$ を代入した量である.また， $M_{u}$ は圧縮フランジの

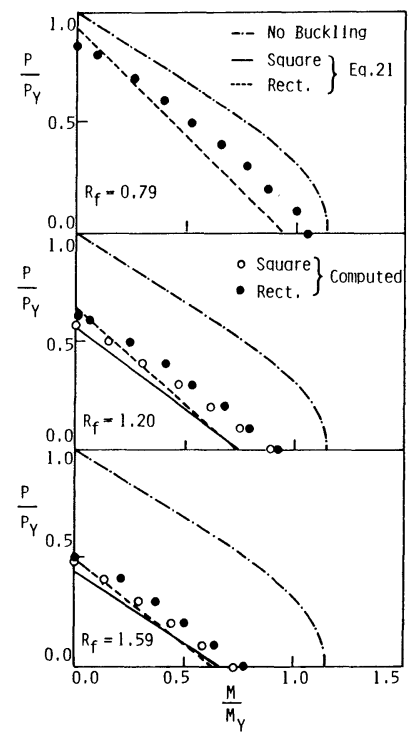

Fig. 11 Interaction Curves of Locally Buckled Column Segments.

局部座屈を考えた極限曲げモーメンドである，図より わかるように, 式 (21) の相関式は, ごく狭い部分を除き, 計算値に比べ安全側にある。また，計算値は，幅厚比 $R_{f}$ が大きくなるに従い直線に近くなり，式（21）のよ うな直線式を用いる妥当性がうかがえる，なお，現行道 路橋示方書では, 式 (21) の $Q, M_{u}$ として式 (22), (23) よりさらに安全な(小さい值を与える)式を用い, しかも, 式 $(21)$ 左辺第 2 項の分母を $M_{u}\left(1-P / P_{E}\right)$ (ただし, $P_{E}$ は長柱のオイラ一座屈荷重) としているため, 式 (21) よりさらに安全側となる.

\section{5. 結言}

鋼薄板により構成される短柱の局部座屈後の弾塑性有 限変位挙動の解析手法を提示し, 純圧縮単独板要素およ び圧縮と曲げを受ける箱形断面短柱に対する数値計算結 果について述べた．解析手法は混合法による有限要素法 を用いた。この研究によって得られた結論をまとめると 次のようになる.

（1）残留応力および初期たわみを同時に考慮した短 柱の弾塑性有限変位解析手法を提示した。

（2）変位場は線形式で仮定しているため,“接線剛 性マトリックス”の計算が非常に簡単である.

（３）移動座標法における剛体変位除去の手法も, 変 位法 ${ }^{5)}$ に比べ格段に簡単である.

（4）純圧縮板に対する本解析結果は現在最も信頼で きるといわれている Little の解 ${ }^{8)}$ 23) と大きな差がない.

（5）単独板要素の平均応力-平均ひずみ関係を構成 板要素材料の応力-ひずみ関係とみなして短柱の $M-P-$ 
$\Phi$ 曲線を求める方法 (Little の方法 ${ }^{4)}$ ) は軸方向圧縮力 が小さい場合以外信頼できる結果を得ることができな い.

（6）式（21）で表わされる短柱の極限強度の相関式 は解析結果に対し, 安全側の式となっている (Fig. 11 参 照).

数值計算はすべて本学大形計算機センターの FACOM M 382 を使用した. 本研究の初期の段階で討議に加わっ ていただいた, 愛知工業大学の青木徹彦助教授に感謝す る.

\section{Appendix I 汎関数 $\Delta \boldsymbol{I}_{R}^{e}($ 式 (6)) の誘導}

Fig. 1 に示す三角形要素の節点 $i(i=1,2,3)$, 節辺( $(k=1,2,3)$ で定義される次の量を導入する.

$\Delta \boldsymbol{u}_{p}^{T}=\left[\Delta u_{1}, \Delta u_{2}, \Delta u_{3}, \Delta v_{1}, \Delta v_{2}, \Delta v_{3}\right]$

$\Delta \overline{\boldsymbol{p}}_{p}^{T}=\left[\Delta \bar{p}_{x 1}, \Delta \bar{p}_{x 2}, \Delta \bar{p}_{x 3}, \Delta \bar{p}_{y 1}, \Delta \bar{p}_{y 2}, \Delta \bar{p}_{y 3}\right]$

$\Delta \boldsymbol{w}^{T}=\left[\Delta w_{1}, \Delta w_{2}, \Delta w_{3}\right], \Delta \boldsymbol{M}_{n}^{T}=\left[\Delta M_{n 1}, \Delta M_{n 2}, \Delta M_{n 3}\right]$

$\Delta \boldsymbol{M}_{n s}^{T}=\left[\Delta M_{n s 1}, \Delta M_{n s 2}, \Delta M_{n s 3}\right]$

$\Delta \boldsymbol{V}_{n}^{T}=\left[\Delta \bar{V}_{n 1}, \Delta \bar{V}_{n 2}, \Delta \bar{V}_{n 3}\right]$

$\Delta \overline{\boldsymbol{w}}_{n}=\left[\Delta \bar{w}_{, n 1}, \Delta \bar{w}_{, n 2}, \Delta \bar{w}_{, n 3}\right] \cdot$

ここに, $\Delta u_{i}, \Delta v_{i}, \Delta w_{i}$ =節点 $i$ における変位増分 $\Delta u$, $\Delta v, \Delta w ; \Delta \bar{p}_{x i}, \Delta \bar{p}_{y i}=$ 節点 $i$ における節点力増分; $\Delta M_{n k}, \Delta M_{n s k}, \Delta \bar{V}_{n k}, \Delta \bar{w}_{, n k}=$ 節辺凤における $\Delta M_{n}, \Delta M_{n s}$, $\Delta \bar{V}_{n}, \Delta \bar{w}_{n}$ である. また, 要素内で定義される次の記 号を導入する.

$\Delta N^{T}=\left[\Delta N_{x}, \Delta N_{y}, \Delta N_{x y}\right], \Delta M^{T}=\left[\Delta M_{x}, \Delta M_{y}, \Delta M_{x y}\right]$

$\Delta \boldsymbol{x}^{T}=\left[\Delta \varkappa_{x}, \Delta x_{y}, \Delta \varkappa_{x y}\right]$

$\Delta \boldsymbol{e}_{L}^{T}=\left[\Delta u_{, x}, \Delta v_{, y}, \Delta u_{, y}+\Delta v_{, x}\right]$

$\Delta \boldsymbol{e}_{N L}^{T}=\left[1 / 2 \Delta w_{, x}^{2}, 1 / 2 \Delta w_{, y}^{2}, \Delta w_{, x} \Delta w_{, y}\right]$

$\Delta e=\Delta e_{L}+\Delta e_{N L}$

ここで, $\Delta x=\Delta M$ に対応する曲率; $\Delta e_{L}, \Delta e_{N L}=$ 中央面 のひずみ増分の線形, 非線形成分. なお, 式 $(A \cdot 1)$ (A·3) で定義した量の初期応力状態での量は $\Delta$ なしで 用いる.

本解析では変位増分を線形式, 曲げモーメント増分を 要素内で一定と仮定しているので, 変位増分は次式で表 わされる.

$\left\{\begin{array}{l}\Delta u(x, y) \\ \Delta v(x, y)\end{array}\right\}=\left[\begin{array}{llllll}1 & x & y & 0 & 0 & 0 \\ 0 & 0 & 0 & 1 & x & y\end{array}\right]\left[\begin{array}{cc}\boldsymbol{A}^{-1} & 0 \\ 0 & \boldsymbol{A}^{-1}\end{array}\right] \Delta \boldsymbol{u}_{\rho}$

$\Delta w(x, y)=[1, x, y] A^{-1} \Delta w$

ここに

$$
\boldsymbol{A}=\left[\begin{array}{lll}
1 & x_{1} & y_{1} \\
1 & x_{2} & y_{2} \\
1 & x_{3} & y_{3}
\end{array}\right]
$$

であり, $\left(x_{i}, y_{i}\right)$ は節点 $i の ~(x, y)$ 座標である.

$\Delta \Pi_{R 1}^{e} \cdots こ の$ 項はすべて板の曲げ変形に関.する項であ
るため, Herrmann モデルの定式化がそのまま利用でき， 誘導は文献 15）に譲り，結果のみ記す.

$$
\begin{aligned}
\Delta \Pi_{R 1}^{e}= & \Delta \boldsymbol{w}^{T} \boldsymbol{k}_{23} \Delta \boldsymbol{M}_{n}-\Delta \boldsymbol{w}^{T}\left(\Delta \overline{\boldsymbol{q}}+\overline{\boldsymbol{q}}-\boldsymbol{q}^{*}\right) \\
& -\Delta \boldsymbol{M}_{n}^{T}(\Delta \overline{\boldsymbol{\theta}}+\overline{\boldsymbol{\theta}})
\end{aligned}
$$

ここで, $\boldsymbol{k}_{23}=-\boldsymbol{F} \boldsymbol{R} \boldsymbol{E}^{-1}, \overline{\boldsymbol{q}}=\boldsymbol{L} \overline{\boldsymbol{V}}_{n}+\bar{q} A_{e}[1,1,1]^{T} / 3, \overline{\boldsymbol{\theta}}$

$=\boldsymbol{S} \overline{\boldsymbol{w}}_{n}, \boldsymbol{q}^{*}=-\boldsymbol{F} \boldsymbol{R} \boldsymbol{E}^{-1} \boldsymbol{M}_{n}$

$\boldsymbol{E}=\left[\begin{array}{ccc}\cos ^{2} \alpha_{1} & \sin ^{2} \alpha_{1} & \sin 2 \alpha_{1} \\ \cos ^{2} \alpha_{2} & \sin ^{2} \alpha_{2} & \sin 2 \alpha_{2} \\ \cos ^{2} \alpha_{3} & \sin ^{2} \alpha_{3} & \sin 2 \alpha_{3}\end{array}\right]$,

$\boldsymbol{F}=\left[\begin{array}{ccc}-1 & 0 & 1 \\ 1 & -1 & 0 \\ 0 & 1 & -1\end{array}\right]$

$\boldsymbol{R}=\frac{1}{2}\left[\begin{array}{lll}-\sin 2 \alpha_{1} & \sin 2 \alpha_{1} & 2 \cos 2 \alpha_{1} \\ -\sin 2 \alpha_{2} & \sin 2 \alpha_{2} & 2 \cos 2 \alpha_{2} \\ -\sin 2 \alpha_{3} & \sin 2 \alpha_{3} & 2 \cos 2 \alpha_{3}\end{array}\right]$,

$\boldsymbol{L}=\frac{1}{2}\left[\begin{array}{ccc}a_{1} & 0 & a_{3} \\ a_{1} & a_{2} & 0 \\ 0 & a_{2} & a_{3}\end{array}\right]$

$\boldsymbol{S}=\operatorname{diag} .\left(a_{1}, a_{2}, a_{3}\right)$

$(A \cdot 7) \sim(A \cdot 16)$

上式中， $a_{k}$ は節辺凤の長さ， $\alpha_{k}$ は節辺ほの法線 $n$ の $x$ 軸からの角度, diag. $\left(a_{1}, a_{2}, a_{3}\right)$ は対角項が $a_{1}, a_{2}$, $a_{3}$ の $3 \times 3$ の対角行列を表わす. 式 $(\mathrm{A} \cdot 12),(\mathrm{A} \cdot 14)$ の行列 $\boldsymbol{E}, \boldsymbol{R}$ はそれぞれ次式で定義される変換行列で ある.

$$
\Delta \boldsymbol{M}_{n}=\boldsymbol{E} \Delta \boldsymbol{M}, \quad \Delta \boldsymbol{M}_{n s}=\boldsymbol{R} \Delta \boldsymbol{M} \cdots \cdots \cdots \cdots(\mathrm{A} \cdot 17,18)
$$

$\Delta \Pi_{R 2}^{e} \cdots$ コンプリメンタリーエネルギー密度関数の増 分量 $\Delta B$ は次式で与えられる.

$$
\Delta B=\int_{-t / 2}^{t / 2}\left(\Delta \tilde{\boldsymbol{\sigma}}^{T} \widetilde{\boldsymbol{e}}+1 / 2 \Delta \tilde{\boldsymbol{\sigma}}^{T} \Delta \widetilde{\boldsymbol{e}}\right) d z
$$

ここに, $\Delta \tilde{\sigma}$ は要素内任意点の応力増分, $\Delta \widetilde{\boldsymbol{e}}$ は要素内 任意点のひずみ増分で，次式で表わされる.

$$
\Delta \widetilde{\boldsymbol{e}}=\Delta \boldsymbol{e}+z \Delta \boldsymbol{x}
$$

$\tilde{\boldsymbol{e}}$ は要素内任意点の初期応力状態のひずみであるが, 初 期応力状態での座標系では板の中央面は無ひずみと考え てよく, 中央面以外の任意点では曲率 $\boldsymbol{x}$ に対応するひ ずみを考えなくてはならない。すなわち，

$$
\tilde{\boldsymbol{e}}=\boldsymbol{z x}
$$

式 $(A \cdot 20),(A \cdot 21)$ を式 $(A \cdot 19)$ に代入し,

$$
\Delta N=\int_{-t / 2}^{t / 2} \Delta \tilde{\sigma} d z, \Delta M=\int_{-t / 2}^{t / 2} \Delta \tilde{\sigma} z d z
$$

とおくと, 次式を得る.

$$
\Delta B=\Delta M^{T} \boldsymbol{x}+1 / 2\left(\Delta \boldsymbol{e}^{T} \boldsymbol{N}+\Delta \boldsymbol{M}^{T} \Delta \boldsymbol{x}\right)
$$

式 $(\mathrm{A} \cdot 24)$ を式 (5) に代入し, 式 $(\mathrm{A} \cdot 1) \sim(\mathrm{A} \cdot 3)$ の 諸量を導入すれば次式を得る.

$$
\begin{aligned}
\Delta \Pi_{R 2}^{e}= & \iint_{A_{e}}\left[1 / 2 \Delta \boldsymbol{e}^{T} \Delta \boldsymbol{N}-1 / 2 \Delta \boldsymbol{M}^{T} \Delta \boldsymbol{x}+\Delta \boldsymbol{e}^{T} \boldsymbol{N}\right. \\
& \left.-\Delta \boldsymbol{M}^{T} \boldsymbol{x}\right] d A-\Delta \boldsymbol{u}_{p}^{T}\left(\overline{\boldsymbol{p}}_{p}+\Delta \boldsymbol{p}\right) \cdots \cdots \cdots \cdots(\mathrm{A}
\end{aligned}
$$


上式の積分内の第 1 項の $\Delta e$ を $\Delta e_{L}$ で近似し, 式 $(\mathrm{A} \cdot 3)$ 〜 (A.5), (A·17), (A·18) および Appendix Пの構成 則を用い, また, 積分内の各項は要素内で一定であるこ とを考慮し, 式 $(\mathrm{A} \cdot 7)$ と $(\mathrm{A} \cdot 25)$ の和を取れば $\Delta \Pi_{R}^{e}$ は式（6）のようになる.ここに，

$$
\begin{aligned}
& k_{11}=A_{e} B^{T} D_{1} B, \quad k_{13}=A_{e} B^{T} C_{1} E^{-1} \\
& \boldsymbol{k}_{33}=-A_{e}\left(\boldsymbol{E}^{-1}\right)^{T} \boldsymbol{C}_{2} \boldsymbol{E}^{-1}, \quad \boldsymbol{k}_{22}=A_{e}\left(\boldsymbol{A}^{-1}\right)^{T} \boldsymbol{G} \boldsymbol{A}^{-1} \\
& \boldsymbol{p}_{\rho}^{*}=A_{e} \boldsymbol{B}^{T} \boldsymbol{N}, \boldsymbol{\theta}^{*}=A_{e}\left(\boldsymbol{E}^{-1}\right)^{T} \boldsymbol{x} \\
& \boldsymbol{B}=\left[\begin{array}{llllll}
0 & 1 & 0 & 0 & 0 & 0 \\
0 & 0 & 0 & 0 & 0 & 1 \\
0 & 0 & 1 & 0 & 1 & 0
\end{array}\right]\left[\begin{array}{cc}
\boldsymbol{A}^{-1} & 0 \\
& \\
0 & \boldsymbol{A}^{-1}
\end{array}\right] \\
& \boldsymbol{G}=\left[\begin{array}{ccc}
0 & 0 & 0 \\
0 & N_{x} & N_{x y} \\
0 & N_{x y} & N_{y}
\end{array}\right] \cdots \cdots \cdots \cdots \cdots(\mathrm{A} \cdot 26) \sim(\mathrm{A} \cdot 33)
\end{aligned}
$$

上式で $\boldsymbol{B}$ は次式で定義される変換行列である.

$$
\Delta \boldsymbol{e}_{L}=\boldsymbol{B} \Delta \boldsymbol{u}_{\rho}
$$

また, $D_{1}, C_{1}, C_{2}$ は式 $(\mathrm{A} \cdot 36)$ の構成則に現われる行 列であり， $\boldsymbol{k}_{22}$ は通常幾何剛性行列とよばれる行列であ る. $\boldsymbol{k}_{11}, \boldsymbol{k}_{12} \sim \boldsymbol{k}_{33}$ は要素の接線剛性行列を構成するが, これらを求めるためには, 数值積分の必要はない（ただ し構成則を求めるために板厚方向の積分を行う必要はあ る).

\section{Appendix II 構成則}

塑性論におけるひずみ増分理論 ${ }^{15)} に$ 従えば $\Delta \tilde{\boldsymbol{\sigma}}$ と $\Delta \tilde{\boldsymbol{e}}$ の間には

$$
\Delta \tilde{\sigma}=D^{e \rho} \Delta \tilde{\boldsymbol{e}}
$$

が成り立つ.ここに $D^{e p}$ は弾塑性応力マトリックスで 具体的な形は文献 15）に与えられている. いま $\Delta \tilde{\boldsymbol{e}} \cong$ $\Delta e_{L}+z \Delta x$ と近似し, 式 $(\mathrm{A} \cdot 35)$ を式 $(\mathrm{A} \cdot 22),(\mathrm{A} \cdot 23)$ に代入し変形すれば

$$
\left\{\begin{array}{c}
\Delta N \\
\Delta x
\end{array}\right\}=\left[\begin{array}{cc}
D_{1} & C_{1} \\
-C_{1}^{T} & C_{2}
\end{array}\right]\left\{\begin{array}{l}
\Delta e_{L} \\
\Delta M
\end{array}\right]
$$

を得る.ここに,

$$
\begin{aligned}
& D_{1}=D_{11}-D_{12} D_{22}^{-1} D_{12}^{T}, \quad C_{1}=D_{12} D_{22}^{-1}, \quad C_{2}=D_{22}^{-1} \\
& D_{11}=\int_{-t / 2}^{t / 2} D^{e \rho} d z, \quad D_{12}=\int_{-t / 2}^{t / 2} D^{e \rho} z d z \\
& D_{22}=\int_{-t / 2}^{t / 2} D^{e p} z^{2} d z
\end{aligned}
$$

である. 式 $(A \cdot 36)$ が本解析で用いられる構成則である. なお，式 $(\mathrm{A} \cdot 38)$ の積分するため，本解析では板厚を 4 等分割し, 分割点での応力状態から定まる $D^{e p} よ り$ Simpsonの積分公式より計算した.

1）宇佐美勉・福本唀士・青木徹彦：溶接箱形断面柱の局部
座屈と全体座屈の連成強度に関する実験的研究, 土木学 会論文報告集，第 308 号，1981 年 4 月.

2）宇佐美勉・福本唀士：鋼圧縮部材の連成座屈強度実験と 有効幅理論による解析, 土木学会論文報告集, 第 326 号, 1982 年 10 月.

3) Galambos, T.V. (福本唀士・西野文雄訳)：鋼構造部材 と骨組一強度と設計一, 丸善, 1970 年.

4) Little, G. H. : The Strength of Square Steel Box Columns, The Structural Engineer, Vol.57 A, No.2., Feb., 1979.

5）小松定夫・北田俊行・宮崎清司：残留応力および初期た わみを有する圧縮板の弾塑性解析, 土木学会論文報告集, 第 244 号, 1975 年 12 月.

6）小松定夫 ・北田俊行：初期不整を有する圧縮板の極限強 度特性に関する研究, 土木学会論文報告集, 第 270 号, 1978 年 2 月.

7）吉田 裕・増田陳紀・松田 隆：薄板で構成される立体 構造の弾塑性・大変形離散化要素解析法, 土木学会論文 報告集, 第 288 号, 1979 年 8 月.

8) Bradfield, C.D. : An Evaluation of the Elastic-Plastic Analysis of Plates Loaded by Uniaxial In-Plane Compression, Int. J. Mech. Sci., Vol.24, No. 3, 1982.

9) Bradfield, C.D. and Stonor, R.W. P. : Simple Collapse Analysis of Plates in Compression, Journal of Structural Engineering, ASCE, Vol.110, No.12, Dec., 1984.

10) Tahiani, C. and Lachnce, L. : Linear and Nonlinear Analysis of Thin Shallow Shells by Mixed Finite Elements, Computers and Structures, V̀ol. 5, 1975.

11) Noor, A. K. and Hartley, S. J. : Nonlinear Shell Analysis Via Mixed Isoparametric Elements, Computers and Structures, Vol.7, 1977.

12) Noor, A. K. and Andersen, C. M. : Mixed Models and Reduced/Selective Integration Displacement Models for Nonlinear Shell Analysis, Int. J. Num. Meth. Engrng. Vol. 18, 1982.

13) Herrmann, L. R. : Finite Element Bending Analysis for Plates, J. Engr. Mech. Division, ASCE, Vol.93, No. EM 5, Oct. , 1967.

14) Washizu, K. : Variational Methods in Elasticity and Plasticity, 3rd ed., Pergamon press, 1982.

15）山田嘉昭編：マトリックス法の応用，東大出版会，1972.

16) Owen, D.R.J. and Hinton, E. : Finite Elements in Plasticity, Pineridge Press Limited, 1980.

17) Moxham, K.E. : Compression in Welded Web Plates, Ph. D. Thesis, Univ. of Cambridge, 1970.

18) Little, G. H. : Rapid Analysis of Plate Collapse by Live Energy Minimization, Int. J. Mech. Sci., Vol.19, 1977.

19) Fukumoto, Y. and Itoh, Y. : Basic Compression Strength of Steel Plates from Test Data, Proc. JSCE, No. 344/ I -1, April, 1984.

20) Bradfield, C.D. : Tests on Plates loaded in In-Plane Compression, J. Const. Steel Res. Vol.1, No. 1, 1980.

(1985.2.27 - 受付) 